\title{
The Use of Bliss Symbols as a First Step into Literacy with Four Children with Down Syndrome
}

\author{
Erna Alant \\ Centre for Augmentative and Alternative Communication \\ Department of Communication Pathology, University of Pretoria,Pretoria
}

\begin{abstract}
This study describes the use of Bliss symbolics as a first step into literacy with four children with Down syndrome in a preschool setting. Initial stages of the intervention programme are discussed as well as the children's ability to read Bliss symbols six months after commencement of the programme. Symbol errors are analyzed and implications for further research discussed.
\end{abstract}

\section{OPSOMMING}

Hierdie studie beskryf die gebruik van Bliss-simbole as eerste stap tot geletterdheid by vier kinders met Downsindroom in 'n voorskoolse opset.Inisiële stadiums van die intervensieprogram is bespreek asook die kinders se vermoë om die Bliss-simbole te lees ses maande na aanvang van die program. Simboolfoute is geanaliseer en implikasies vir verdere navorsing bespreek.

Literacy is an important skill which facilitates the integration of disabled people into society. This is not only because of the print-dominant society we live in, but also because exposure to print enriches the individual's language and facilitates further conceptual and metalinguistic abilities (Blackstone, 1989; Koppenhaver \& Yoder 1992; Van Kleeck; 1992).

Traditionally children who had no or limited verbal expression were involved in speech/language programmes and not in reading programmes as it was believed that they did not have sufficient language skills to read (Koppenhaver \& Yoder, 1992). A consequence of this has been limited exposure of cognitively handicapped children to reading instruction, particularly in cases where children havé a specific language learning deficit, for example Down syndrome (Stoel-Gammon, 1990).

Recently, however, researchers have opposed this view, for example, Raver \& Dwyer (1986) who demonstrated a relationship between the reading and language ability of the 5 preschool mentally handicapped children involved in a conversational approach to teaching. They argued that although it was typically believed that reading instruction must be postponed until a child's expressive language is "ready", the results of their study did not support this assumption.

Apart from limited exposure to instruction, the success of teaching literacy to cognitively handicapped people has been limited. The reasons for this failure are multiple, including, poor teaching strategies (Kuntz, Carrier \& Hollis, 1978; Raver \& Dwyer, 1986), children's limited language ability (Hern, Smith \& Fuller, 1992;
Stoel-Gammon 1990), limited level of abstraction and poor concentration (Jeffree, 1981; Matson \& Mulick, 1991). Wishart (1990:250) maintained that many professionals still hold outdated conceptions of the nature of Down syndrome and of its developmental implications and indicated that "sufficient evidence has already accumulated to suggest that with the appropriate support and input, children with Down syndrome in future generations will undoubtedly fare better than previously". The nature of the support needed, however, constitutes a major point of controversy which has led to a critical review of present methods used to enhance literacy development.

The methodology of teaching literacy to cognitively handicapped individuals has focused mainly on the teaching of sight vocabulary in order to give entrance into as broad a vocabulary of written words as possible. The underlying assumption is that auditory and visual processing of the cognitively handicapped person are delayed and that they would not be able to cope with the complex skills of analyses and syntheses in reading (for example word attack skills). Cognitively handicapped people will therefore learn to read in the same way as cognitively-able people although at a slower rate with little focus on word attack skills. The teaching of sight vocabulary limits the person's reading to a number of words which is, however, no longer sufficient. Folk \& Campbell (1978) pointed out that trainers must find techniques that will allow trainable cognitively handicapped children to read recipes, newspaper items, movie schedules, vocation information, store signs and so forth. "The question is not whether trainable level students 
are competent enough to acquire basic reading skills, but whether we as special educators are competent enough to teach them." (Folk \& Campbell, 1978:322). Alternative teaching strategies are particularly important in view of the heterogeneity in language performance found in cognitively restricted children where a single systematic pattern of language and cognitive development is highly unlikely (Miller \& Chapman, 1984). Kangas \& Lloyd (1988:211) support this argument by stating "..a model of child development may not be a sufficient framework for selecting goals of intervention for children and adults who experience severely disabling conditions and who are functioning at early levels with respect to developmental norms". Wishart (1990) agrees with this notion and stresses that particularly in the case of Down syndrome, early learning styles differ fundamentally from those seen in non-handicapped children.

The pathways and processes used to process information by the child are thus at the basis of the different methods and systems in teaching language and literacy skills. McNaughton (1992) discusses that processing differences occur between children who are ablebodied and those who have speech and physical impairments and hypothesizes that the different pathways make a difference to the way in which they process information and thus influence their learning to read. Children who use a visual system instead of speech for communication may be able to compensate for the limitations they face in speech production domains. This suggests that severely communicatively handicapped children can get access to reading through a different symbolic pathway than that of normal children as this may provide an easier transition to normal orthography (Romski, Sevcik, Pate \& Rumbaugh, 1985).

Various authors have suggested that "bridging" between pictures and print seem to be an effective teaching strategy with cognitively handicapped individuals (Jeffree, 1981; McNaughton, 1992). Apart from the children learning to read words quicker, more reading fluency is achieved with resulting positive confidence with the task (Jeffree, 1981).

Different symbol systems have been used to enhance literacy skills in cognitively handicapped children by providing a "bridge" to normal orthography, e.g., Rebus, Makaton, Bliss. The use of Bliss symbols for entrance into literacy have been propagated particularly in view of the extensive vocabulary and range of symbols available that can be combined to create new concepts (Burroughs, Albritton, Eaton \& Montague, 1990; Shepherd \& Haaf, 1992). Although Bliss has been used extensively with cognitively handicapped children, there is little doubt that these symbols are more difficult to learn than some of the other symbol systems e.g., Pics and Rebus (Mizuko, 1987). This feature which refers to the more abstract nature of some of the symbols could be seen as part of the reason why this system is an appropriate bridge into literacy. The combination of symbols also creates the opportunity for analysis and synthesis skills to develop on a visual level before these skills are required in normal orthography. There have, however, not been any studies done on the association between analysis and synthesis skills on a conceptual level (for example, Bliss) and reading ability. At most this relationship could be defined as loose, although the basic concept of analysis and synthesis in relation to reading is introduced before facilitating these skills in normal orthography.

One could argue that the teaching of a conceptually based symbol system before teaching normal orthography could delay the actual reading process. Superficially, this may seem to be the case, as the child will take longer before "reading" normal orthography. The extended world knowledge and exposure to concepts will, however, contribute to easier and more extensive access to reading once exposed to the process. Similarly, it could be said that exposure to Bliss symbols and normal orthography simultaneously could lead to cognitive overload as children may have problems in retaining two symbol systems (Light \& Lindsay, 1991). As one system is conceptually based, while the other is letter based, however, they refer to two different functional systems which may facilitate information processing (Underwood, 1978).

The process of reading instruction with symbols can be described in three phases: phase 1, the teaching of symbols; phase 2, the sequencing of symbols; and phase 3 , the fading of symbols to expose normal orthography only (Kuntz et al:, 1978). This study aims to describe the initial phase of teaching new symbols to four children with Down syndrome, followed by a description of the sentence reading they were doing 6 months later. A qualitative description of symbol errors is made and discussed in order to shed some light on the symbol acquisition of the children.

\section{METHOD}

The goals of this study were firstly to describe four cognitively handicapped children's ability to learn Bliss symbols within a ten week period in order to use Bliss symbolics as an entrance into literacy. The subgoals were threefold: firstly to study the process of learning Bliss symbols in terms of recognition and labelling, secondly to investigate the children's conceptual ability in relation to symbols taught during this period and thirdly, to describe the children's Bliss reading six months after the final training period. Finally a qualitative description of the symbol errors is made.

\section{SUBJECTS:}

Four children with Down syndrome enrolled at a nursery school for disabled children in Pretoria were included in the study. All the children were in the same class in the preschool specifically geared to the needs of children with Down syndrome (see Table 1 for a description of the subjects).

Table 2 gives more detail on the present communication abilities of the children.

\section{PROCEDURE:}

The Bliss symbols were taught as part of the regular preschool curriculum. The teacher, selected the symbols according to the theme for the particular period. The number of symbols used each period varied according to the need identified by the teacher (see Table 3). 
- Teaching of symbols: Each theme was introduced in the same manner and the same school routine was used during the eight weeks of implementation. In the teaching of the symbols, particular steps were followed by the teacher which will be discussed below.All of these steps included teaching within a group setting. The daily routine during the eight weeks was as follows:
* Day 1: Experiencing the concepts.

- All the children of the school went on an outing which was related to the theme of that week [see Table 3 for an outline of the themes].

- The aim of the outings was to provide the children with the real experience and to bring them into contact with the actual objects. The teacher focused the

Table 1. Description of subjects $(\mathrm{N}=4)$

\begin{tabular}{|c|c|c|c|c|}
\hline Characteristics & Subject 1 & Subject 2 & Subject 3 & Subject 4 \\
\hline Chronological age [years \& months] & 7,2 & 5,7 & 5,5 & 3,7 \\
\hline Mental age [years \& months] & 4,0 & 2,11 & 3,8 & 2,6 \\
\hline Home language & Afrikaans & Afrikaans & Afrikaans & Afrikaans \\
\hline Syndrome & Down & Down & Down & Down \\
\hline Hearing & Normal & Normal & Normal & Normal \\
\hline Previous exposure to Bliss [months] & 18 & 3 & 12 & 3 \\
\hline Socio-economic status & Middle & Middle & Middle & Middle \\
\hline Gender & Male & Male & Male & Female \\
\hline
\end{tabular}

Table 2. Communication and visual perceptual abilities of the children

\begin{tabular}{|c|c|c|c|c|c|}
\hline Evaluation & Measurement tools & Subject 1 & Subject 2 & Subject 3 & Subject 4 \\
\hline $\begin{array}{l}\text { Chronological } \\
\text { age (CA) }\end{array}$ & & $\begin{array}{l}\text { [CA:86 } \\
\text { months] }\end{array}$ & $\begin{array}{l}\text { [CA: } 67 \\
\text { months }\end{array}$ & $\begin{array}{l}\text { [CA:65 } \\
\text { months] }\end{array}$ & $\begin{array}{l}\text { [CA:43 } \\
\text { months] }\end{array}$ \\
\hline $\begin{array}{l}\text { Receptive } \\
\text { vocabulary }\end{array}$ & *PPVT & $\begin{array}{l}\text { extremely } \\
\text { poor }\end{array}$ & $\begin{array}{l}\text { extremely } \\
\text { poor }\end{array}$ & $\begin{array}{l}\text { extremely } \\
\text { poor }\end{array}$ & - \\
\hline $\begin{array}{l}\text { Receptive } \\
\text { language }\end{array}$ & $\begin{array}{l}\text { *TACL } \\
\text { Sub tests: } \\
\text { - word'classes and relations } \\
\text { - grammatical morphemes } \\
\text { - elaborated sentences } \\
\text { *RDLS comprehension }\end{array}$ & $\begin{array}{l}49-53 \text { months } \\
42-45 \text { months } \\
56-58 \text { months } \\
-\end{array}$ & 33 months & $\begin{array}{l}\text { 30-31 months } \\
29-31 \text { months } \\
28-31 \text { months } \\
-\end{array}$ & 31 months \\
\hline $\begin{array}{l}\text { Expressive } \\
\text { language }\end{array}$ & $\begin{array}{l}\text { *MLU } \\
\text { *Predicted chronological } \\
\text { age }\end{array}$ & $\begin{array}{l}>6 \\
>58.3 \\
\text { months }\end{array}$ & $\begin{array}{l}2.00 \\
26.9 \\
\text { months }\end{array}$ & $\begin{array}{l}5.6 \\
55.2 \\
\text { months }\end{array}$ & $\begin{array}{l}1.9 \\
26.1 \\
\text { months }\end{array}$ \\
\hline $\begin{array}{l}\text { Pragmatic } \\
\text { behaviour }\end{array}$ & $\begin{array}{l}\text { *Checklist of pragmatic } \\
\text { behaviour }\end{array}$ & Good & Average & Average & Poor \\
\hline $\begin{array}{l}\text { Cognitive } \\
\text { development }\end{array}$ & ${ }^{*}$ DASI 2 developmental age & 48 months & 35 months & 44 months & 30 months \\
\hline $\begin{array}{l}\text { Visual } \\
\text { perception }\end{array}$ & $\begin{array}{l}\text { *Developmental test of visual } \\
\text { perception } \\
\text { *Developmental test of visual } \\
\text { motor integration }\end{array}$ & 57.2 months & 35.6 months & 52.7 months & $\begin{array}{l}\text { not } \\
\text { available }\end{array}$ \\
\hline
\end{tabular}

PPVT: Peabody Picture Vocabulary Test; Afrikaans translation by Gouws (1975).

TACL: Test of Auditory Comprehension of Language; Afrikaans translation by Kritzinger (1985).

CA: Chronological age.

RDLS: Reynell Developmental Language Scales (Reynell \& Huntley, 1985).

MLU: Mean Length of Utterance; Computation according to Miller, 1981.

Pragmatic behaviour: Good: 60-100\% of communicative intents and conversational devices were observed;

Average: $30-60 \%$

Poor: $0-30 \%$

DASI 2: Developmental Activities Screening Inventory (Fewell \& Langley, 1984).

Developmental test of visual perception (Frostig, 1963).

Developmental Test of Visual Motor Integration (Beery, 1967). 
children's attention on concepts which were to be included in training and provided language stimulation throughout the outing. A video recording was made by one of the teachers, which was used in teaching later on in the week.

- No formal work was done on day 1 , as the children left for home after the outing. No Bliss symbols were thus introduced on day 1.

* Day 2:Introduction of pictures, objects and symbols.

On day 2 the class was introduced to the interest table. This table contained objects and/or toys of the vocabulary to be taught. The teacher and the children had an informal discussion about the objects and related it back to their outing. New concepts were explained, demonstrated and acted out where necessary, in order to highlight the meanings of the concepts. This table was displayed in the classroom throughout the day.After this the interest board was introduced containing the symbols and pictures.Pictures were matched to the objects on the object table and then put onto the interest board, followed by the Bliss symbol for that particular object/picture.

- The Blissymbol-interest board was displayed in the classroom throughout the week.This procedure was followed with all the symbols to be taught.

The Bliss symbols were presented as follows:

* global presentation of the Bliss symbol on a flashcard

* naming of the symbol

* association of the symbol with the objects and pictures

* identification of indicators [plural and action indicators]

* As soon as all the new symbols were introduced, the teacher made short sentences with the Bliss symbols and the children had to read them. New and old symbols were used in the sentences. The teacher also asked comprehension questions, where children had to match the correct picture to the sentence.
- Drill practise:

After the groupwork, the teacher worked with the children individually for approximately 10 minutes a day in order to reinforce the meaning of the symbols.The work done in school was sent home and it was expected of the parents to reinforce the sentences at home.

- The same procedure was followed for the remainder of the time period in which the theme was used.New symbols were introduced every day and objects/toys on the object board were added on a daily basis.

- Testing of symbols for the study:

* Each child was tested individually on the different occasions at school. The symbols were taught over an extended period of 10 weeks, but due to school and public holidays the period of exposure varied for each theme. During this time some children were also absent for a number of days due to illnesses or personal reasons. See Table 3 for detail about exposure time.

* Baseline testing (before intervention) : In the beginning of a new training period, each child was evaluated to determine if he/she was familiar with the concepts that were to be taught and whether he/she recognized or was able to label the Bliss symbols that were going to be taught. Three pictures or symbols were presented and the child was requested to point to the specific picture or symbol. As the speech of some of the children was unintelligible, the evaluation of the ability to label Bliss symbols had to be adapted. The symbol was presented and the child was asked to label it or to match it with the picture. A choice of three pictures was given once again. Items that were indicated by trial and error were repeated in order to increase reliability.

At the end of each period of teaching, the same procedure was followed to evaluate the number of concepts learned as well as the children's ability to recognize and label newly taught symbols (middle evaluation). A final evaluation (two weeks after intervention stopped) of all the concepts and symbols taught since the begin-

Table 3. Symbols taught during each period

\begin{tabular}{|c|c|c|c|c|}
\hline & Period 1 & Period 2 & Period 3 & Period 4 \\
\hline Theme: & Wild animals & Insects & Birds & Good habits \\
\hline Period of exposure (days): & 6 days & 6 days & 8 days & 8 days \\
\hline $\begin{array}{c}\text { Bliss symbols: } \\
\text { nouns }\end{array}$ & $\begin{array}{l}\text { elephant } \\
\text { monkey } \\
\text { lion } \\
\text { giraffe } \\
\text { rhinoceros } \\
\text { hippopotamus }\end{array}$ & $\begin{array}{l}\text { bee } \\
\text { butterfly } \\
\text { grasshopper } \\
\text { museum }\end{array}$ & $\begin{array}{l}\text { duck } \\
\text { owl } \\
\text { ostrich } \\
\text { parrot }\end{array}$ & $\begin{array}{l}\text { dentist } \\
\text { teeth } \\
\text { hair } \\
\text { vegetables } \\
\text { fruit } \\
\text { milk }\end{array}$ \\
\hline verbs & $\begin{array}{l}\text { swing } \\
\text { is }\end{array}$ & $\begin{array}{l}\text { sit } \\
\text { fly } \\
\text { jump }\end{array}$ & $\begin{array}{l}\text { run } \\
\text { swim }\end{array}$ & $\begin{array}{l}\text { bath } \\
\text { brush } \\
\text { eat } \\
\text { drink }\end{array}$ \\
\hline other & $\begin{array}{l}\text { big } \\
\text { small }\end{array}$ & on & $\begin{array}{l}\text { high } \\
\text { fast }\end{array}$ & $\begin{array}{l}\text { I } \\
\text { my }\end{array}$ \\
\hline
\end{tabular}


ning of the period was conducted to determine how much was retained over this period.

Finally, an analysis was made 6 months later to determine progress in terms of Bliss reading.

\section{RESULTS AND DISCUSSION}

Figures 1, 2, and 3 represent the global results of all 4 candidates over the eight weeks as regards their scores on the baseline, middle and final evaluations of the concepts introduced, ability to recognize and label Bliss symbols.

From this diagram it is clear that all four children showed an increase in their understanding of the concepts over the 8 weeks. It is interesting that two of the candidates, subject 2 and 3 , showed slightly less understanding ( $9 \%$ and $8 \%$ ) in the final evaluation than in the middle evaluation. This decrease could be because concepts were not internalized well enough before proceeding to the new concepts resulting in the elimination from short term memory.

From figure two it is evident that 2 candidates did not recognize any symbols before training started, while two candidates recognized $32 \%$ and $40 \%$ respectively. Once again, it is clear that all the candidates scored better in the final evaluation. As in the previous figure, candidates 2 and 3 again showed a slight decrease (2\% and $7 \%$ ) in performance from the middle to final evaluation. Although a smaller decrease than in the conceptual evaluation, this could be explained against the background of information processing models, whereby recognition is seen as a much easier skill in the information processing process (Light \& Lindsay, 1991).

A similar pattern is observed in figure 3 where all the subjects showed an increase in the labelling of Bliss symbols over the total period. Although a labelling re-

Figure 1. Overall conceptual performance of the subjects.
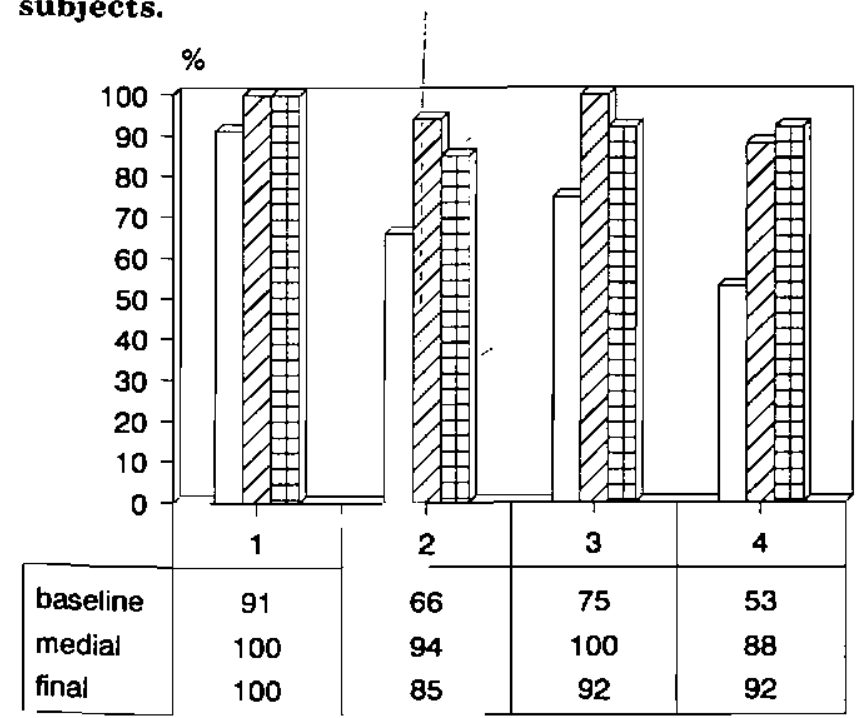

Subject sponse was not only scored on a verbal level (the child could also label by matching the picture to the symbol), it was interesting to note that there was an increase of verbal labelling from one of the candidates. Once again, however, subjects 2 and 3 as well as subject 1 in this case, showed a decrease in scores from the middle to the final evaluations. Labelling, (being the most difficult of the three skills in terms of information process-

Figure 2. Overall recognition of Bliss symbols in baseline, medial and final evaluations.

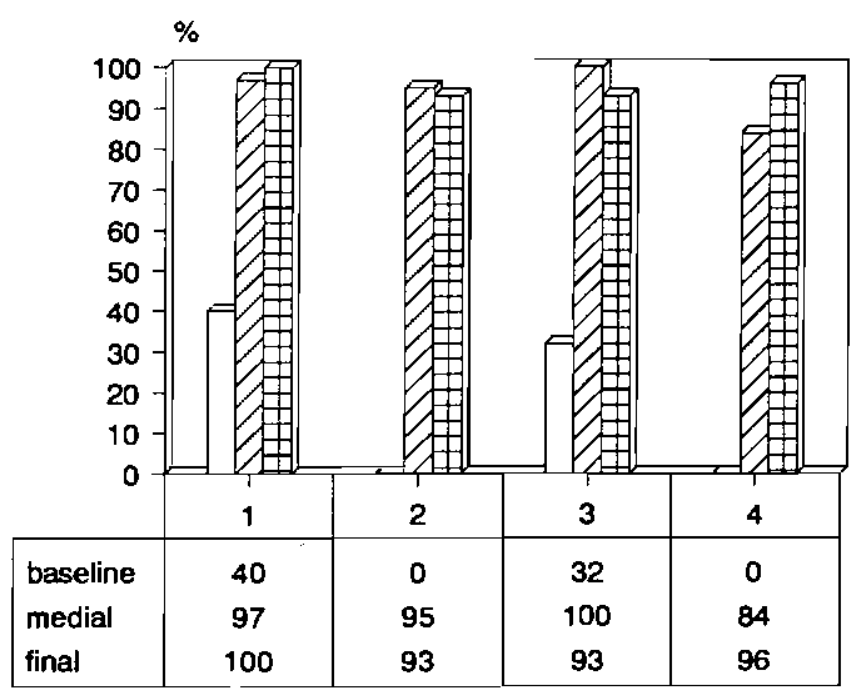

Subject

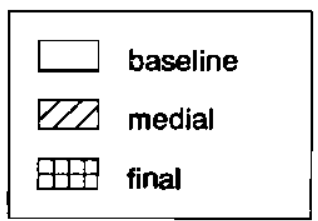

Figure 3: Overall labelling of Bliss symbols in baseline, medial and final evaluations

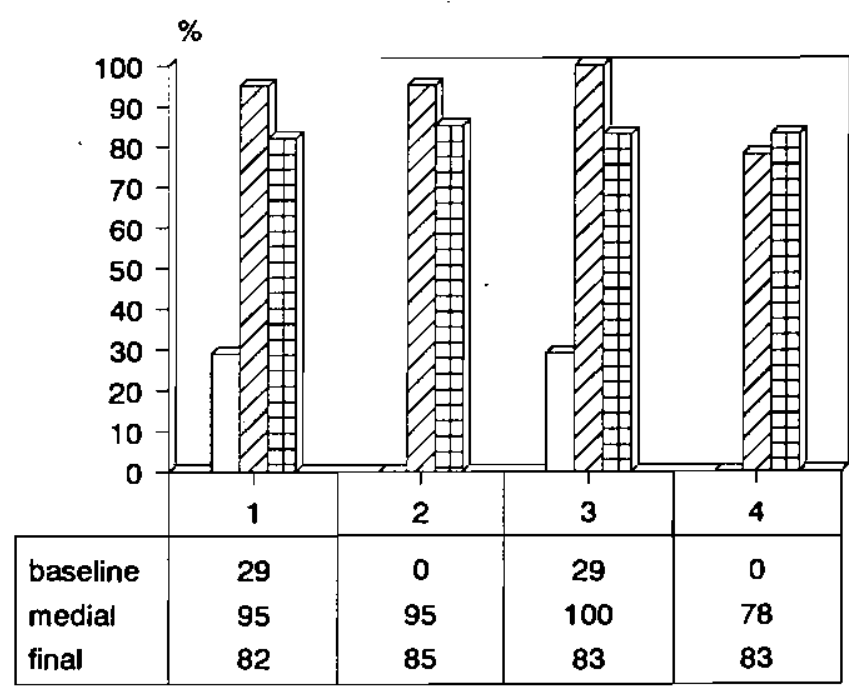

Subject
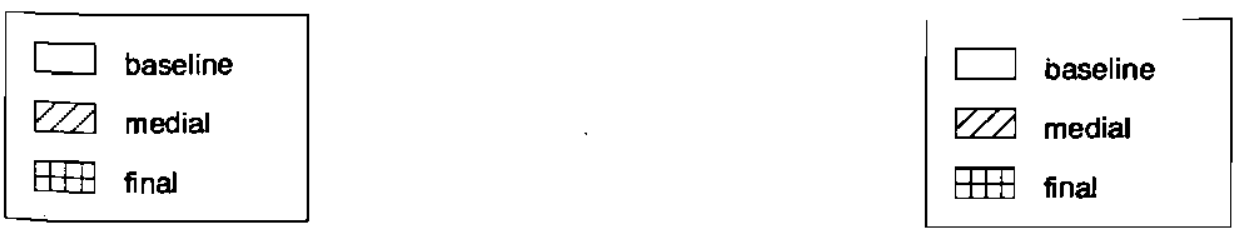
ing and production) was most affected by the two week time lapse before final testing.

Although Bliss symbols have been criticized for being more difficult for children to learn than other sym- bol systems e.g., Pics and Rebus (Goosens, 1983; Hurlbut, Iwata \& Green, 1982), most of the children in this study were able to learn the different symbols. The retention of concepts and symbolic skills over eight

\section{Table 4. Qualitative description of subjects' symbol errors}

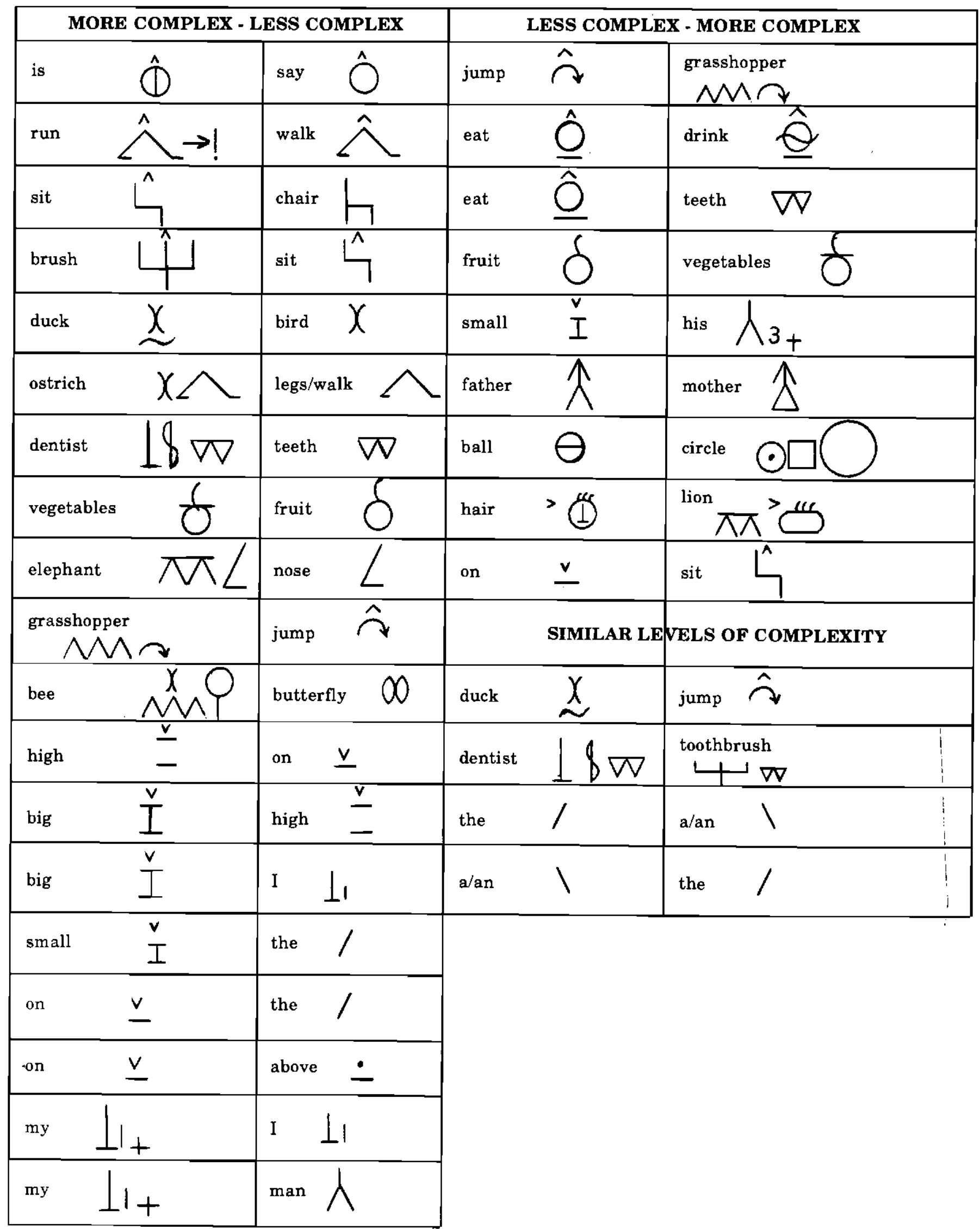


weeks suggests that the programme provided the children with a stable and functional Bliss reading skill (Romski, Sevcik \& Rumbaugh, 1985).

\section{ANALYSIS OF SYMBOL ERRORS MADE BY THE FOUR CHILDREN}

Table 4 represents the kind of errors the children made in terms of visual complexity (number of strokes and elements in the symbol; Fuller \& Lloyd, 1987). From this table it is clear that from the 30 errors identified, $63 \%$ can be categorized as being visually less complex than the stimulus symbol, $30 \%$ can be categorized as visually more complex than the stimulus symbol and $7 \%$ stayed constant in terms of complexity.

The visual simplifications may be interpreted against the visual perceptual difficulties of the children as all the children had some visual processing problems (refer Table 2). It also can be an attempt at reducing complexity in order to reduce overload of the cognitive system (Light \& Lindsay, 1991). This finding is in accordance with the research done by Fuller \& Lloyd (1987) in which they found that complexity has a detrimental effect on the learning of symbols.

It is, however, interesting to note that all the errors that were made were not reduction errors. $30 \%$ of the substitute symbols were more complex than the original stimuli.

Table 4 suggests that the meaning of the concept and the transparency of the symbol were the main criteria for selection of a symbol. For example, the symbol for jump is substituted with grasshopper. The symbol for grasshopper is a much stronger sign for indicating jumping as it has repetitive up and down movement (zigzag). The symbol for eat is substituted for drink and teeth. A strong semantic similarity exists between concepts for the child e.g., he eats with his teeth; on instead of sit. It could also be an indication that the children are unsure of the symbols and need more exposure in order to familiarize themselves with them. In particular, it is indicated that the children are confusing verbs and nouns, ignoring the indicators above the symbols. These features could be indicative of too little time spent explaining individual elements to the children or that the children are not grasping the meaning of abstract indicators.

Children often identified one characteristic or element of a symbol and then generalized it to another e.g., dentist became toothbrush; hair became lion. They were able to recognize the identifying elements, but were less successful in applying them to the correct combined symbol elements. This behaviour could be another attempt at reduction of stimuli (gist recall), although the children were aware that it needed to be combined with another element or symbol. Goossens' (1983) findings that suggested that students with a moderate cognitive impairment and no memory problems had more problems with Bliss symbols than other graphic representational systems (e.g., PICS), also support the higher cognitive demands on the child when learning Bliss symbols due to the symbols being less iconic in nature.

From this table it is clear that complexity of symbols

Table 5: Sentence reading after 6 months

\begin{tabular}{|c|c|c|c|}
\hline Subjects & 2 & 3 & 4 \\
\hline DIE BY VLIEG. [The bee flies.] & $100 \%$ & $100 \%$ & $67 \%$ \\
\hline DIE BY SIT OP DIE BLOM. [The bee sits on the flower.] & $100 \%$ & $83 \%$ & $100 \%$ \\
\hline DIE SPRINKAAN SPRING. [The grasshopper jumps.] & $100 \%$ & $100 \%$ & $67 \%$ \\
\hline DIE SPRINKAAN HET VOELERS. [The grasshopper has tentacles.] . & $75 \%$ & $100 \%$ & $75 \%$ \\
\hline DIE SPRINKAAN EET GRAS. [The grasshopper eats grass.] & $75 \%$ & $75 \%$ & $100 \%$ \\
\hline DIE PAPEGAAI IS BAIE MOOI. [The parrot is very pretty.] & $80 \%$ & $80 \%$ & $40 \%$ \\
\hline DIE EEND SWEM IN DIE WATER. [The duck swims in the water.] & $83 \%$ & $100 \%$ & $83 \%$ \\
\hline DIE VOLSTRUIS HARDLOOP VINNIG. [The ostrich runs fast.] & $75 \%$ & $50 \%$ & $75 \%$ \\
\hline DIE APIE SWAAI. [The monkey swings.] & $100 \%$ & $67 \%$ & $100 \%$ \\
\hline DIE APIE IS KLEIN. [The monkey is small.] & $100 \%$ & $50 \%$ & $100 \%$ \\
\hline DIE OLIFANT IS GROOT. [The elephant is big.] & $75 \%$ & $100 \%$ & $100 \%$ \\
\hline EK DRINK MY MELK. [I drink my milk.] & $100 \%$ & $100 \%$ & $100 \%$ \\
\hline EK EET MY GROENTE. [I eat my vegetables.] & $100 \%$ & $50 \%$ & $75 \%$ \\
\hline EK EET VRUGTE. [I eat fruit.] & $67 \%$ & $67 \%$ & $67 \%$ \\
\hline EK BORSEL MY HARE. [I brush my hair.] & $100 \%$ & $75 \%$ & $75 \%$ \\
\hline
\end{tabular}


(number of elements or strokes) is not sufficient in explaining the behaviour of the children and that the behaviour of the children can only be described when factors like iconicity, exposure time, and teaching strategy are also taken into account.

\section{BLISS READING PERFORMANCE OF THE SAME CHILDREN AFTER 6 MONTHS OF INSTRUCTION}

Table 5 represents the reading done in the classroom after six months' Bliss instruction. One of the children left the school during this period, leaving three candidates.

From this table it is clear that all three candidates could read the majority of Bliss symbols correctly. Although these scores do not reveal whether the child understands what he has read, it certainly reflects entrance into the process of reading. Although the teacher's subjective evaluation revealed that the children understood what they were reading, a formal study on the children's reading comprehension ability would be of primary importance particularly in view of the proposal by Nettelbeck \& Lally (1976) that cognitively restricted individuals have less efficiency in accumulating and holding signals in order to decode.

\section{CONCLUSION}

Generally the children had little difficulty in learning the Bliss symbols. An increase in conceptualization, recognition and labelling was noted with all the children. As no controls were used, one cannot suggest that these increases are the results of the implementation of Bliss symbols in the classroom. However, the changes indicate gains for the children over a period of eight weeks. One of the children's mode of labelling used during the project also changed from predominantly nonverbal to more consistent verbal labelling attempts which is consistent with other reports on the facilitating effect that AAC systems can have on speech development (Kangas \& Lloyd, 1988).

The reading fluency in Bliss symbolics obtained by the subjects also indicates that this process is worth investigating as an entrance into the process of reading and language enrichment. As most of the concepts introduced are concrete (low level of abstraction), a systematic approach towards extending their conceptual reading is necessary. Some systematic planning needs to be done in order to determine at which point Bliss symbols should be faded away. At present, however, indications are that extensive work on Bliss symbolics needs to be done in order to give the children sufficient exposure to conceptual reading and to reinforce receptive skills.

The symbol errors indicated that transparency as well as the complexity of symbols were important characteristics in understanding the errors made by the children. Confusion between symbols of similar meaning occurred which could either indicate not enough exposure to particular symbols or that too many symbols were introduced too soon. When observing the overall success in recognition and labelling of Bliss symbols, the last alternative seems unlikely.

Finally, it was clear that there were several symbol confusions that occurred due to the children not being able to remember the differentiating indicators of the
Bliss symbols (for example, chair instead of sit). This could indicate the necessity of more focus on element training in the Bliss programme to ensure that the children learn to analyze and synthesize symbol elements in order to facilitate more extensive entrance into Bliss reading.

The use of Bliss symbolics as an entrance into literacy highlights many issues in relation to the process of learning to read, particularly in severely handicapped children. These issues vary from the evaluation of the most effective way to introduce, extend and eventually fade the use of Bliss symbols to the understanding of the information processing skills of the cognitively restricted person. In these ways, the use of Bliss symbolics not only facilitates the children's language development, but also contributes to the development of new information regarding the process of reading acquisition.

\section{ACKNOWLEDGEMENTS}

The assistance of Enid Moolman in the fieldwork and preparation of the study is highly appreciated.

The co-operation of the teachers at the Nursery Group for Children with Language and Hearing Problems, University of Pretoria, is also much appreciated.

\section{REFERENCES}

Beery, K.E. (1967). Developmental test for visual-motor integration. Cleveland: $\mathrm{OH}$ Modern Curriculum.

Blackstone, S.W. (Ed.) (1989). Literacy development and remediation in AAC: Scratching the surface. Augmentative Communication News, 2(1), 1-4.

Burroughs, J.A., Albritton, E.G., Eaton, B.B. \& Montague, J.C. (1990). A comparative study of language delayed preschool children's ability to recall symbols from two symbol systems. Augmentative and Alternative Communication, 6(3), 203206.

Fewell, R. \& Langley, M.B. (1984). Developmental Activities Screening Inventory. (DASI II). Austin: Pro Ed.

Folk, M.C. \& Campbell, J. (1978). Teaching functional reading to the TMR. Education and training of the mentally retarded, 13(3), 322-326.

Frostig, M.F. (1963). Developmental test of visual perception. California, Palo Alto.

Fuller, D.R. \& Lloyd, L.L. (1987). A study of physical and semantic characteristics of a graphic symbol system as predictors of perceived complexity. Augmentative and Alternative Communication, 3(1), 26-35.

Goossens, C.A. (1983). The relative iconicity and learnability of verb references differentially represented by manual signs, Bliss symbols, and Rebus symbols: an investigation with moderately retarded individuals. Dissertation Abstracts International, 45 (03), 809-A.

Gouws, K.J. (1975). Peabody Picture Vocabulary Test : (Afrikaans Translation).

Hern, S., Smith, J. \& Fuller, D.R. (1992). The effects of translucency, complexity, and other variables on the acquisition of Bliss symbols by institutionalized individuals. (Submitted for publication in Mental Retardation).

Hurlbut, B.I., Iwata, B.A. \& Green, J.D. (1982). Nonvocal language acquisition in adolescents with severe physical disabilities: Bliss symbol versus iconic stimulus formats. Journal of Applied Behaviour Analysis, 15, 241-248.

Jeffree, D. (1981). A bridge between pictures and print. Special Education: Forward trends, 8(1), 28-31.

Kangas, K. \& Lloyd, L. (1988). Early cognitive skills as prerequisites to augmentative and alternative communication use: what are we waiting for? Augmentative and Alternative Communication, 4(4), 211-221.

Koppenhaver, D.A. \& Yoder, D.E.'(1992). Literacy learning of children with severe speech and physical impairments in school settings. Seminars in Speech and Language, 13(2), 143-153. 
Kritzinger, A. (1985). Afrikaans translation of the "Test of Auditory Comprehension of Language II" (TACL). Original composer: Carrow-Woolfolk. Texas: DLM Teaching Resources.

Kuntz, J.B., Carrier, J.K. \& Hollis, J.H. (1978). A nonvocal system for teaching retarded children to read and write: In C.E. Meyers, (Ed.); Quality of life in severely and profoundly mentally retarded people: Research foundations for improvement. (pp. 145-191). Washington, D.C.: American Association on Mental Deficiency Monograph.

Light, J. \& Lindsay, P. (1991). Cognitive Science and Augmentative and Alternative Communication. Augmentative and Alternative Communication, 7(3), 186203.

Matson, J.L. \& Mulick, J.A. (eds) (1991). Handbook of Mental Retardation. New York: Pergamon Press.

McNaughton, S. (1992). Parents and symbols: Charting the language pathway together. Communicating together, $10(3), 20-21$.

Miller, J. (1981). Assessing Language Production in Children. Baltimore: University Park Press.

Miller, J. F. \& Chapman, R. (1984). Disorders of Communication: investigating the development of language of mentally retarded children. American Journal on Mental Deficiency, 88(5), 536-545.

Mizuko, M. (1987). Transparency and ease of learning of symbols represented by Bliss symbols, PCS, and Picsyms. Augmentative and Alternative Communication, 3(3), 129136.
Nettelbeck, T \& Lally, M. (1976). Inspection time and measured intelligence. American Journal on Mental Deficiency, 83, 398-401.

Raver, S.A. \& Dwyer, R.C. (1986). Teaching handicapped preschoolers to sightread using language training procedures. The Reading Teacher, 40(3), 314-321.

Reynell, J.K. \& Huntley, M. (1985). Reynell Developmental Language Scales (2nd revision) Windsor: NFER-Nelson.

Romski, M.A., Sevcik, R.A. \& Rumbaugh, D.M. (1985). Retention of symbolic communication skills by severely mentally retarded persons. American Journal of Mental Deficiency, 89 (4), 441-444.

Romski, A., Sevcik, R., Pate, J. \& Rumbaugh, D. (1985) Discrimination of lexigrams and traditional orthography by nonspeaking severely mentally retarded persons. American Journal on Mental Deficiency, 90(2), 185-189.

Shepherd, T.A. \& Haaf, R. (1992). A comparison of two training methods of Bliss symbols. Paper presented at ISAAC conference, Philadelphia.

Stoel-Gammon, C. (1990). Down syndrome. ASHA, 32, 42-44.

Underwood, G. (1978). Strategies for Information Processing. London: Academic Press.

Van Kleeck, A. (1992), Language assessment and intervention in children. Guest lecturer, Department of Speech Pathology and Audiology, University of Pretoria.

Wishart, J. G. (1990). Learning to learn: the difficulties faced by infants and young children with Down syndrome. In W.I.Fraser, (Ed.); Key Issues in Mental Retardation Research. London: Routledge. 


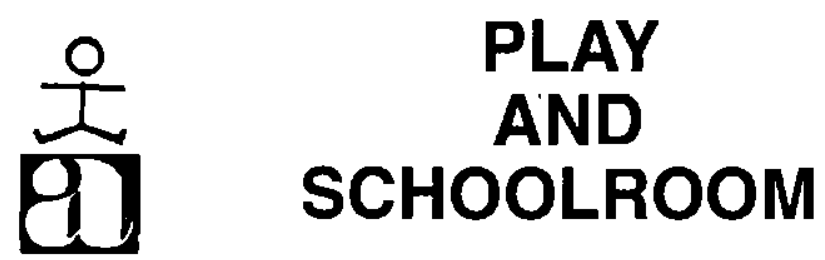

SHOP 6L THE ROSEBANK MEWS 173 OXFORD ROAD ROSEBANK JHB.

TESTS, PROGRAMMES, BOOKS, TEACHING AIDS, JOURNALS AND RESOURCES

FOR

CHILD DEVELOPMENT

SPEECH \& LANGUAGE

LEARNING DISABILITIES

SPECIAL NEEDS

ADULT REHABILITATION

PO BOX 52137

FAX: 880-1341

SOCIAL ACTIVITIES 